\title{
ACUTE TOXICITY ANALYSIS OF EFFLUENT FROM TANNERY INDUSTRY IN KANO METROPOLIS
}

\author{
Ibrahim, S. S. and Imam, T. S.*
}

Biological Sciences Department, Bayero University, Kano

*Corresponding author: tsimam.bio@buk.edu.ng; GSM No.: 08133382562

\begin{abstract}
The acute toxicity of tannery effluents collected from Challawa industrial estate Kano, Nigeria was assessed using Artemia salina and Clarias gariepinus. The test was done after the evaluation of range finding test before a definitive test with 3 replication of each treatment. The varying concentrations were prepared by diluting crude effluent with borehole water on $V / V \%$ in a completely randomized design. The experiment showed C. gariepinus fingerling to exhibit abnormal behavior such as initial erratic movement, skin discolouration and loss of reflex. Recorded mortality and behavioral abnormalities in both species observed were dose-time-dependent. The 96 hours $L C_{50}$ estimated for $C$. gariepinus was $9.95 \%$ while that of $A$. salina after 24 hours and 48 hours were $4.63 \%, 0.73 \%$ respectively. Thus, the information from the study demonstrates the toxic effect of tannery effluent which requires proper management before its discharge into environment.
\end{abstract}

Keywords: Acute toxicity, Artemia salina, Clarias gariepinus, Effluent, Tannery

\section{INTRODUCTION}

For the last few years, particularly in Africa, there is a significant increase in human population. The resultant increase in the activities of human such as urbanization and economic activities causes detrimental effect to our environment (Bernand and Ogunleye, 2015). For developing countries like Nigeria, environmental problems are growing at faster rate due to lack of enforcement of laws (Wakawa et al., 2008).

For across the globe, it is estimated that each year, tannery industries discharge 300-400 million tons of pollutants into water bodies (Chowdhury et al., 2015). Historically, Nigeria has about 41 commercial tanneries designed more to process skins than hides, with most of them predominantly based in Kano (USAID, 2012). These industries witnessed boom in production, making it second to only oil in terms of foreign exchange earnings according to CBN reports by FMenv (2012). There operational processes involve transforming of raw hide or skin into leather used in the manufacturing of a wide range of products (Ado et al., 2014). During the process, tanning agents are used which generate highly turbid, coloured and foul smelling effluent (Yusif et al., 2016). The major problem of tannery effluent is heavy metals, toxic chemicals, chloride, lime with high dissolved and suspended salt and other pollutants it contains (Jahan et al., 2014).

The number of investigation carried out with vertebrate specie on exposure to tannery effluent is low (Souza et al., 2016). Although there is considerable amount of literature published on characterization of tanneries/textile effluents in Kano as reported by Akan et al. (2009), Ezike et al. (2012), Bernand and Ogunleye (2015), and Umar et al. (2017) among many other researchers, there is little or no documented report on acute and chronic toxicity test of the effluent. The method of acute toxicity testing of the effluent normally involves the use of organisms such as luminous bacteria, algal, crustaceans and fish (Xiao et al., 2016). It is recommended to be carried out using at least two different animal species.

The fish species ( $C$. gariepinus) is of importance because of its cultivation as food and widely found free living in freshwater of Nigeria. Furthermore, brine shrimp has been proposed for toxicity testing due to its simplicity, inexpensiveness and reliable short term routine. This research focuses on assessing acute toxicity of effluent from a tannery industry in Kano metropolis using test organisms; $C$. gariepinus and a simple crustacean ( $A$. salina). These will contribute to our knowledge through establishing information on toxic effects of the discharged effluent to aquatic life. Information obtained can also help in formulating control measures to discharge chemicals and monitoring the environment.

\section{MATERIALS AND METHODS}

Study Sites and Effluent Source

Located in the Northern part of Nigeria, Kano State lies between latitude $12^{\circ} 40^{\circ}$ and $10^{\circ} 30^{\circ}$ and longitude $7^{\circ} 40^{\circ}$ and $9^{\circ} 40^{\circ}$. 
Special Conference Edition, November, 2019

The effluent was collected some few meters away from point of discharge of a tannery industry in Chalawa industrial estate (an area that houses most of the well known leather finishing company). The Grab sample of effluent produced was collected using clean jerry cans washed with water and then rinsed with the effluent. A portion was analysed for physicochemical parameters (Temperature, $\mathrm{pH}$, DO and salinity) using combined water quality meter model 8603.

\section{Experimental Organisms Set-up}

In accordance to Olowa and Nuneza, (2013), Artemia salina eggs were obtained and hatched in artificial seawater with minor modification as the first experimental organism.

Juveniles Clarias gariepinus of size $7.5-8.5 \mathrm{~cm}$ and weight $2.9-3.6 \mathrm{~g}$ were employed as second experimental organism. They were purchased from Rumbun Kifi Dorayi, Kano state. The fishes were acclimatized for fourteen days and fed with commercial feed of $1 \mathrm{~mm}$ size. Feeding was stopped for 24 hours prior to and during exposure period that lasted for 96 hours.

\section{Acute Toxicity Assay}

At first, range finding test was evaluated with six concentration of the effluent at dilution $6.25 \%$, $12.5 \%, 25 \%, 50 \%$, $100 \%$ using clean filtered artificial seawater with adjusted salinity of 30ppt. Using static bioassay, ten Artemia salina larvae of less than 24 hour old were transferred to petri dishes containing $10 \mathrm{ml}$ of prepared samples. The test was run in three replicates for 48 hours and immobilization/mortality was recorded (Krishnakumar et al., 2007). The second test was carried out following the same process with proper care with additional concentrations; $3.16 \%$ and $1.56 \%$ to reduce error and obtain a credible result.

For the second experimental organism, range finding test was carried out using non static renewal bioassay with $6.25 \%, 12.5 \%, 25 \%$, $50 \%, 100 \%$ and $0 \%$ concentrations and 10 fishes per chamber set in duplicate. A definitive concentration at 25\%, $12.5 \%, 9.00 \%, 6.25 \%$, $3.16 \%, 1.56 \%$ was later employed. The experiment was set up in triplicate placing 6 fishes per chamber so as to reduce and refine for result credibility. Careful observations were made by taking into account the behavioral/morphological responses and mortality after 12, 24, 48, 72 and 96 hours (Olorunfemi et al., 2014) of test organisms.

\section{Statistical Analysis}

Data was analysed using SPSS version 16.0 for probit facility. The mortalities was calculated, corrected and converted to probit $\left(\mathrm{LC}_{50}\right)$ (Kelle et al., 2013). The $\mathrm{LC}_{50}$ toxic value was transformed into toxic unit and safe concentrations using the equation;

- $\mathrm{TU}=100 / \mathrm{LC}_{50}$

- $\quad$ Safe concentration limit $=\mathrm{LC}_{50} \times 0.1$ 2013)

Where 0.1 is application factor (Workagegn,

\section{RESULTS AND DISCUSSION}

In Table 1 below, temperature and $\mathrm{pH}$ mean value were $29.92 \pm 1.93^{\circ} \mathrm{C}$ and $8.14 \pm 0.85$ respectively, revealing that they were within the standard permissible limit of WHO (2012). The mean value of DO recorded was below standards and could cause stress to aquatic life. Dilution water (borehole water) physicochemical parameters measured were within the permissible limits (WHO, 2012).

Table 1: Some Major Physicochemical Parameters (mean \pm SD) of the Tannery Effluent and Borehole Water as Compared to WHO Standard

\begin{tabular}{lccc}
\hline \multicolumn{1}{c}{ Parameters } & Effluent discharge & Borehole Water & WHO (2012) \\
\hline Temperature $\left({ }^{\circ} \mathrm{C}\right)$ & $29.92 \pm 1.93$ & $28.53 \pm 0.65$ & $30-36$ \\
pH & $8.14 \pm 0.85$ & $6.88 \pm 0.72$ & $6.5-8.5$ \\
DO $(\mathrm{mg} / \mathrm{l})$ & $1.60 \pm 0.38$ & $7.02 \pm 0.04$ & 10 \\
Salinity $(\mathrm{mg} / \mathrm{l})$ & $7.75 \pm 0.60$ & $0.03 \pm 0.02$ & - \\
\hline
\end{tabular}

Key: DO = Dissolved Oxygen

\section{Behavioral Response:}

During acute test with $C$. gariepinus, organisms exhibited distress behavioral responses. They were observed directly to have shown sudden change in the organism's response to the environment such as restlessness, gasping for breath and frequent surfacing (prominent during the first hours) which increases as the concentration increases. As time went on, the test organisms were observed to get weaker with ventral surface turned upward and eventually die. This observed behavior corresponds with the study of Adewoye (2010) that observed visible behavioural change after 60 minutes of $C$. gariepinus exposure to Trephosia vogelii extracts. Similar symptoms of toxicosis was reported by Emere and Balogun (2014) with subacute behaviours including agitated swimming, loss of balance, hitting against the edges of the tank, air gulping, quiescence and death peeling off of the skin and swollen abdomen. 
Special Conference Edition, November, 2019

Also of noticeable changes observed at the end of test were spine curvatures, discoloration of body, trace of haemorrhage and cannibalism at higher concentrations, with normalcy in behaviour only at concentration from $9.0 \%$ downward. Moreover, weights of the test organisms were found to have undergone reduction with shrinkage noticed at the head region. The result was in consistent with findings of many authors when respectively studying acute toxic effect of different effluent to $C$. gariepinus. Olaifa et al. (2004), Navraj and Yasmin (2012), Adeboyejo et al. (2013), Dahunsi and Oranusi (2012), Dahunsi and Oranusi (2013), Olorunfemi (2014), Agboola and Fawole (2014) and Olorunfemi et al. (2015).
The stressful behavior of respiratory impairment observed prior to mortality may be related to depletion of oxygen as suggested by Ariyomo et al. (2017). The research identified behavioral response and mortality (Table 2) to be concentration-dependant, increases and decreases as exposure time increase. However, observed behavioral response reinforce evidence that there are three phases of response to effluent, viz; active, fatigue and collapse.

The mortality details recorded from both of the acute assays were presented in Table 2 and Table 3. However, result obtained was further unveiled in Table 4 to shows estimated $\mathrm{LC}_{50}$, toxic unit and safe concentration of both experimented organisms.

Table 2: Mortality Details of $C$. gariepinus During Acute Exposure to Varying Concentrations of Tannery Effluent $(n=6)$

\begin{tabular}{|c|c|c|c|c|c|c|c|c|c|c|c|c|c|c|c|}
\hline \multirow{2}{*}{$\begin{array}{c}\text { Concentration } \\
(\%)\end{array}$} & \multicolumn{3}{|c|}{$12 \mathrm{hr}$} & \multicolumn{3}{|c|}{$24 \mathrm{hr}$} & \multicolumn{3}{|c|}{$48 \mathrm{hr}$} & \multicolumn{3}{|c|}{$72 \mathrm{hr}$} & \multicolumn{3}{|c|}{$96 \mathrm{hr}$} \\
\hline & $\mathrm{R} 1$ & $\mathrm{R} 2$ & R3 & R1 & R2 & R3 & $\mathrm{R} 1$ & R2 & R3 & $\mathrm{R} 1$ & R2 & R3 & $\mathrm{R} 1$ & R2 & R3 \\
\hline 25.0 & 6 & 5 & 6 & 0 & 1 & 0 & 0 & 0 & 0 & 0 & 0 & 0 & 0 & 0 & 0 \\
\hline 12.5 & 1 & 0 & 2 & 2 & 1 & 2 & 3 & 3 & 2 & 0 & 2 & 0 & 0 & 0 & 0 \\
\hline 9.0 & 0 & 0 & 0 & 0 & 0 & 0 & 0 & 0 & 0 & 0 & 0 & 0 & 1 & 1 & 0 \\
\hline 6.25 & 0 & 0 & 0 & 0 & 0 & 0 & 0 & 0 & 0 & 0 & 0 & 0 & 0 & 0 & 1 \\
\hline 3.16 & 0 & 0 & 0 & 0 & 0 & 0 & 0 & 0 & 0 & 0 & 0 & 0 & 0 & 0 & 0 \\
\hline 1.56 & 0 & 0 & 0 & 0 & 0 & 0 & 0 & 0 & 0 & 0 & 0 & 0 & 0 & 0 & 0 \\
\hline 0.00 & 0 & 0 & 0 & 0 & 0 & 0 & 0 & 0 & 0 & 0 & 0 & 0 & 0 & 0 & 0 \\
\hline
\end{tabular}

$\mathrm{R}=$ Replicates

Table 3: Mortality Details of $A$. salina During Acute Exposure to Varying Concentrations of Tannery Effluent $(n=10)$

\begin{tabular}{ccccccc}
\hline Concentration (\%) & \multicolumn{3}{c}{$\mathbf{2 4 h r}$} & \multicolumn{4}{c}{$\mathbf{4 8 h r}$} \\
\cline { 2 - 7 } & R1 & R2 & R3 & R1 & R2 & R3 \\
$\mathbf{1 0 0}$ & 10 & 10 & 10 & 0 & 0 & 0 \\
$\mathbf{5 0}$ & 10 & 9 & 10 & 0 & 1 & 0 \\
$\mathbf{2 5 . 0}$ & 10 & 9 & 10 & 0 & 1 & 0 \\
$\mathbf{1 2 . 5}$ & 8 & 5 & 8 & 2 & 4 & 2 \\
$\mathbf{6 . 2 5}$ & 7 & 5 & 4 & 3 & 4 & 4 \\
$\mathbf{3 . 1 6}$ & 4 & 3 & 2 & 5 & 5 & 5 \\
$\mathbf{1 . 5 6}$ & 2 & 1 & 3 & 6 & 6 & 4 \\
$\mathbf{0 . 0 0}$ & 1 & 0 & 0 & 1 & 2 & 2 \\
\hline
\end{tabular}

$\mathrm{R}=$ Replicates

Acute toxicity with $A$. salina (Table 3 ) was also observed to have dose-and time-dependent relationship with mortality most pronounced at the highest concentration (100\%). During a trial test, more $A$. salina were counted alive, this is an indication of an error in counting. Moreover, it may also be from an incorrect technique of hatching the cysts and manipulation of nauplii during experiments. Hence the transferring of unhatched cyst to experiment chamber which hatches later during experiment. This is in line with the findings of Norsworthy (2000) when studying effects of selenium on death of brine shrimps.

The second trial recorded mortality even in control to about $20 \%$ after 48 hours. This could be associated with lack of food (Norsworthy, 2000) or the high sensitiveness of larval bioassay than egg (Krishnakumar et al., 2007). 
Special Conference Edition, November, 2019

Table 4: Summary of Acute Toxicity of Both C. gariepinus and $A$. salina

\begin{tabular}{|c|c|c|c|c|c|c|c|c|c|}
\hline $\begin{array}{c}\text { Test } \\
\text { organisms }\end{array}$ & $\begin{array}{l}24 \mathrm{hrs} \\
\text { LC }_{50} \\
(\%)\end{array}$ & $\begin{array}{c}\text { 24hrs } \\
\text { TUa }\end{array}$ & $\begin{array}{l}\text { Safe } \\
\text { Conc. } \\
(\%)\end{array}$ & $\begin{array}{l}\text { 48hrs } \\
\text { LC }_{50} \\
(\%)\end{array}$ & $\begin{array}{l}\text { 48hrs } \\
\text { TUa }\end{array}$ & $\begin{array}{l}\text { Safe } \\
\text { Conc. } \\
(\%)\end{array}$ & $\begin{array}{c}\text { 96hrs } \\
\text { LC }_{50} \\
(\%)\end{array}$ & $\begin{array}{c}\text { 96hrs } \\
\text { TUa }\end{array}$ & $\begin{array}{c}\text { Safe } \\
\text { Conc. } \\
(\%)\end{array}$ \\
\hline $\begin{array}{l}\text { C. gariepinus } \\
\text { A. salina }\end{array}$ & $\begin{array}{c}- \\
4.63\end{array}$ & $\begin{array}{c}- \\
21.60\end{array}$ & $\begin{array}{c}- \\
0.46\end{array}$ & $\begin{array}{c}- \\
0.73\end{array}$ & $\begin{array}{c}- \\
136.9 \\
9\end{array}$ & $\begin{array}{c}- \\
0.073\end{array}$ & $\begin{array}{c}9.95 \\
-\end{array}$ & $\begin{array}{c}10.05 \\
-\end{array}$ & $\begin{array}{c}0.995 \\
-\end{array}$ \\
\hline
\end{tabular}

Key $\mathrm{TUa}=$ Acute toxic unit, safe concentration

The 96 hours $\mathrm{LC}_{50}$ of acute toxicity with $C$. gariepinus was estimated (Table 4) to be $9.95 \%$. Navaraj and Yasmin (2012) in India, recorded $\mathrm{LC}_{50}$ value of $O$. mossambicus on exposure to tannery effluent as $7 \%$. In a similar study conducted, Dasgupta and Panigrahi (2015) used Labeo rohita and registered concentration even at $3.53 \%$ as highly toxic. These variations in $\mathrm{LC}_{50}$ and behavioural responses values may be linked to differences in the sensitivity of a particular species to pollutant, age, sex and environmental conditions (Olayinka, 2013; Olorunfemi, 2014).

The estimated $\mathrm{LC}_{50}$ for $A$. salina after 24 hours and 48 hours is $4.63 \%$ and $0.73 \%$ as shown in Table 4 is similar to the finding reported in Chile, by Cooman et al. (2003) of $0.36 \%-3.61 \%$ (considered extremely toxic) on testing different tannery processes effluent using Daphnia magna and D. pulex. Baniamam (2014) studied vanadium toxicity using Artemia urmiana and $A$. Franciscana recording $\mathrm{LC}_{50}$ in 24 hours as 0.0107 and $0.011 \mathrm{mg} / \mathrm{L}$. Pimentel et al. (2009) found $\mathrm{LC}_{50}$ values for crude cashew nut industrial effluents $1.38 \%$ and $0.60 \%$ after 24 and 48 hours exposures, respectively, and were $2.16 \%$ and $0.88 \%$ for treated effluent. Further findings base on some authors across the globe recorded acute toxicity $\left(\mathrm{LC}_{50}\right)$ with $A$. salina on exposure to different raw effluents as; $2.73 \%-35.5 \%$ for Chemical plant (Guerra, 2001), 4.5\% for Olive

\section{REFERENCES}

Ado, A., Gumel, S. M. and Garba, J. (2014). Industrial Effluents as Major Source of Water Pollution in Nigeria: An Overview. American Journal of Chemistry and Applications, 1(5):45-50.

Adeboyejo, O.A., Fagbenro, O.A., Adeparusi, E.O. and Clarke, E.O. (2013). Acute Toxicity of Industrial Effluents from Agbara Environment of Ologe Lagoon on Early Life Stages of African Catfish Clarias gariepinus. American Journal of Research Communication, 1(3):50-60.

Adewoye, S.O. (2010). Haematological and Biochemical Changes in Clarias gariepinus exposed to Trephosia vogelii Extract. Advances in Applied Science Research, 1(1):74-79. oil mill (Aggelis et al., 2003), $1.2 \%$ for Oilfield (Campos et al., 2002), 70\%-80\% for Landfill leachate (Svensson et al., 2005), 55\% for Textile (Souza et al., 2007).

Toxic unit estimated in Table 4 for both experimented organisms were far above 0.3TUa, a value set by NYS DEC (2007) as SPDES permit program guidance for protection and survival of aquatic organisms. Classification of toxicity for wastewater discharged of Ross (1993) cited in Libralato et al. (2010) ranked the estimated $\mathrm{LC}_{50}$ of the effluent as class I (highly toxic). In contrast, Personne et al. (2003) cited in Libralato et al. (2010) categorise calculated toxic unit of the 24 hours and 48 hours of acute $A$. salina toxicity to class II (slight acute toxicity) and class I (no acute toxicity) while 96 hours acute of C. gariepinus toxicity as class IV (high acute toxicity).

\section{CONCLUSION}

C. gariepinus subjected to varying concentrations of tannery effluent showed respiratory disturbance and sudden death. In the same regard, $A$. salina was recorded to have a high mortality. The toxicity of the two tested organisms varies greatly with increase in concentration of effluent. Both of the tested organisms in terms of $\mathrm{LC}_{50}$ revealed effluent as highly toxic with estimation of $9.95 \%, 4.63 \%$ and $0.73 \%$ respectively.

Agboola, O.A. and Fawole, O.O. (2014). Chronic Toxicity of Pharmaceutical Effluent to Clarias gariepinus (Burchell, 1822). Covenant Journal of Physical and Life Sciences (CJPL), 1(2):27-42.

Aggelis, G., Iconomou, D., Christou, M., Bokas, D., Kotzailias, S., Christou, Z., Tsagou, V. and Papanikolaou, S. (2003). Phenolic Removal in a Model Olive Oil Mill Wastewater Using Pleurotus ostreatus in a Bioreactor Cultures and Biological Evaluation of the Process. Water Research, 37:3897-3904.

Akan, J.C., Ogugbuaja, V.O., Abdulrahman, F.I. and Ayodele, J.T. (2009). Pollutant Levels in Effluent Samples from Tanneries and Textiles of Kano Industrial Areas, Nigeria. Global Journal 
Special Conference Edition, November, 2019 of Pure and Applied Sciences, 15(3):343-352.

Baniamam, M. (2014). Determination of Lethal Concentration (LC50) Values of Vanadium and Toxicity Effect on the Growth of Artemia urmiana and $A$. Franciscana. Journal of Survey in Fisheries Sciences, 1(1):1-8.

Bernard, E. and Ogunleye, A. (2015). Evaluation of Tannery Effluent Content in Kano Metropolis, Kano State Nigeria. International Journal of Physical Sciences, 10(9):306-310.

Campos, J. C., Borges, R. M. H., Oliveira Filho, A. M., Nóbrega, R. and Sant'anna, Jr. G. L. (2002). Oilfield Wastewater Treatment by Combined Microfiltration and Biological Processes. Water Research, 36:95-104.

Cooman, K., Gajardo, M., Nieto, J., Bornhardt, C. and Vidal, G. (2003). Tannery Wastewater Characterization and Toxicity Effects on Daphnia spp. Environ. Toxicol., 18:45-51.

Chowdhury, M., Mostafa, M.G., Biswas, T.K., Mandal, A. and Saha, A.K. (2015). Characterization of the Effluents from Leather Processing Industries. Environ. Process., 2(5):173.

Dahunsi, S.O., and Oranusi, S.U. (2012). Acute Toxicity of Synthetic Resin Effluent to African Catfish, Clarias gariepinus (Burchell, 1822). American Journal of Food and Nutrition, 2(2):42-46.

Dasgupta, S. and Panigrahi, A.K.R. (2015). Studies on Morphological and Behavioral Alterations of a Freshwater Fish, Labeo rohita Exposed to Tannery Effluents in Ramsar Wetland of West Bengal, India. Journal of Environment and Sociobiology, 47-48.

Emere, M.C. and Balogun, J.K. (2014). Histopathology of Clarias gariepinus Fingerlings Exposed to Kaduna Textile Limited (KTL) Effluents. International Journal of Fisheries and Aquatic Studies, 2(2):256-260.

Ezike, N.N., Udiba, U.U., Ogabiela, E.E., Akpan, N.S., Odey, M.O., Inuwa, B., Sule, A.M. and Gauje, B. (2012). Assessment of the Performance of Primary Effluent Treatment Plant of Major Tanneries in Kano, Nigeria. Trends in Advanced Science and Engineering, 5(1):38-45.

Federal Ministry of Environment, (2012). An Inventory of Hazardous Materials in Tannery and Pulp Industries in Nigeria. Africa Institute for the Environmentally
Sound Management of Hazardous and other Waste.

Guerra, R. (2001). Ecotoxicological and Chemical Evaluation of Phenolic Compounds in Industrial Effluents. Chemosphere, 44:1737-1747.

Jahan, M. A. A., Akhtar, N., Khan, N. M. S., Roy, C. K., Islam, R. and Nurunnabi (2014). Characterization of Tannery Wastewater and its Treatment by Aquatic Macrophytes and Algae. Bangladesh Journal of Scientific and Industrial Research, 49(4):233-242.

Kelle, H.I., Akpuaka, M.U. and Oguezi, V.U. (2013). Analysis and Acute Toxicity Determination of the Dyestuff in the Effluent of a Textile Manufacturing Company Located in the Eastern Part of Nigeria. Journal of Environmental Science, Toxicology And Food Technology, 7:1.

Krishnakurmar, P.K., Dineshbabu, A.P., Sasikumar, G. and Bhat, G.S. (2007). Toxicity Evaluation of Treated Refinery Effluent using Brine shrimp (Artemia salina) Egg and Larval Bioassay. Fishery Technology, 44(1):85-92.

Libralato, G., Annamaria, V.G. and Francesco, A. (2010). How Toxic is Toxic: A Proposal for Wastewater Toxicity Hazard Assessment. Ecotoxicol. Environ. Saf., 73:1602-1611.

Navaraj, P.S. and Yasmin J. (2012). Toxicological Evaluation of Tannery Industry Waste Water on Oreochromis mossambicus. Afr. J. Environ. Sci. Technol., 6(9):331-336.

Norsworthy, C.B. (2000). The Effects of Selenium on the Death Rate of Brine Shrimp. Cantaurus, 8:17-19.

NYS DEC. (2007). Technical and Operational Guidance Series 1.3.2 Acute and Chronic Toxicity Testing in the SPDES Permit Program Guidance.

Olayinka, A.S. (2013). Assessment of Toxic Potentials of Cassava Effluent on Clarias gariepinus. International Journal of Agricultural Science and Research (IJASR), 3:157-160.

Olorunfemi, D.I., Olomukoro, J.O. and Anani, O.A. (2014). Acute Toxicity of Produced Water on Clarias gariepinus Juveniles. Studia Universitatis "Vasile Goldiş", Seria Stiintele Vieţii, 24:299-303.

Olowa, F.L. and Nuñeza, M.O. (2013). Brine Shrimp Lethality Assay of the Ethanolic Extracts of Three Selected Species of Medicinal Plants from Iligan City, Philippines. International Research 
Special Conference Edition, November, 2019 Journal of Biological Sciences, 2(11):7477.

Persoone, G., Marsalek, B., Blinova, I., Törökne, A., Zarina, D., Manusadzianas, L., Nalecz-Jawecki, G., Tofan, L., Stepanova, N., Tothova, L. And Kolar, B. (2003). A Practical and User-Friendly Toxicity Classification System with Microbiotests for Natural Waters and Wastewaters. Environmental Toxicology, 18(6):395-402.

Pimentel, M.F., De Lima, D.P., Martins, L.R., Beatriz, A., Santaella, S.T. and Lotufo, L.V.C. (2009). Ecotoxicological Analysis of Cashew Nut Industry Effluents, Specifically Two of its Major Phenolic Components, Cardol and Cardanol. PanAmerican Journal of Aquatic Sciences, 4(3):363-368.

Ross, P., (1993). The Use of Bacterial Luminescence System in Aquatic Toxicity Testing. In: Richardson, M. (Ed.), Ecotoxicology monitoring $1^{\text {st }}$ ed. VCH, Weinheim, New York, pp. 384 Basel, Cambridge, Tokyo.

Souza, S.M.A.G.U., Forgiarini, E. and Souza, A.A.U. (2007). Toxicity of Textile Dyes and their Degradation by the Enzyme horseradish peroxidase (HRP). Journal of Hazardous Materials, 147:1073-1078.

Souza, J.M., Guimarães, A.T.B., Silva, W.A.M., Pereira, C.C.O., Menezes, I P.P. and Malafaia, G. (2016). Tannery Effluent Effects on Vertebrates: Lessons from Experimental Animals. International Journal of Current Research, 8(10):39902-39914.

Svensson, B.M., Mathiasson, L., Martensson, L., Bergstrom, S. (2005). Artemia salina as Test Organism for Assessment of Acute Toxicity of Leachatewater from Landfills. Environmental Monitoring and Assessment, 102:309-321.

USAID. (2012). Subsector Assessment of the Nigerian Hides and Skins Industry. The United States Agency for International
Development (USAID)/Nigeria RAISE IQC Contract No. PCE-I-00-99-00003-00 Agricultural Development Assistance in Nigeria (ADAN) Task Order No. 812.

Umar, M., Ibrahim, M. A., Mustapha, M. B., Mohammed, I. B., Tashi, U. T., Obafemi, A. and Ahmad, G. I. (2017). Physicochemical Analysis and Microbiological Assessment of Tannery Effluent Discharged from Tanneries around Nigeria's Kano Industrial Estates. Journal of Advances in Microbiology, 2(1) Article no.JAMB.31437.

Wakawa, R.J., Uzairu, A., Kagbu, J.A. and Balarabe, M.L. (2008) Impact assessment of effluent discharge on physicochemical parameters and some heavy metal concentrations in surface water of River Challawa Kano, Nigeria. African Journal of Pure and Applied Chemistry, 2(10):100-106.

Workagegn, K.B. (2013). Toxicity Evaluation of Waste Treatment Plant of Textile Effluent Using Fish: Nile tilapia, Oreochromis niloticus. International Journal of Aquaculture, 3(10):43-48.

World Health Organization, (WHO). (2012). Potential Pollutants, their Sources and their Impacts. Guideline for Drinking Water quality (electronicResource). Retrieved from http://www.whglibdoc.who.int/publicatio ns/2006/9241546964.eng.pdf.

Xiao, N., Qin, L., Zhang, X., Li, Y. and Zhang, F. (2016). Industrial Wastewater Biological Toxicity Research Status. International Conference on Energy and Environmental Protection (ICEEP), 521526.

Yusif, B. B., Bichi, K. A., Oyekunle, O. A., Girei, A. I., Garba, P. Y. and Garba, F. H. (2016). A Review of Tannery Effluent Treatment. International Journal of Applied Science and Mathematical Theory, 2(3):29-43. 